\title{
ZONE RECRYSTALLIZATION OF ZIRCONIUM AND HAFNIUM
}

\author{
DOleh E. Kozhevnikov*, (D)Mykola M. Pylypenko, (D)Maryna F. Kozhevnikova \\ NSC "Kharkiv Institute of Physics \& Technology" NASU \\ 1, Academichna str., 61108, Kharkiv, Ukraine \\ *Corresponding Author: kozhevnikov@kipt.kharkov.ua \\ Received December 4, 2020; revised February 21, 2021; accepted February 22, 2021
}

\begin{abstract}
The work studied the possibility of obtaining of the high-purity samples of zirconium and hafnium by the method of zone recrystallization of round rods with electron-beam heating in a vacuum of $1 \cdot 10^{-4} \mathrm{~Pa}$. Some meltings were carried out in a constant electric field with the variability of its connection. It is shown that the simultaneous passage of several refining processes (evaporation of highly volatile metallic impurities, zone recrystallization with directional displacement of impurities to the end of the sample, electrotransport) made it possible to efficient refining of zirconium both from metallic impurities and from interstitial impurities. The best degree of purification was achieved when zone melting carrying out in an electric field directed opposite to the zone movement. In this case, the displacement of interstitial impurity ions coincided with the direction of movement of the liquid zone. Samples of zirconium with a purity of 99.89 wt. \% were obtained (the concentration of aluminum was reduced by 5 , iron - 11 , copper -45 , chromium -75 , silicon - 10 , titanium -2.5 , oxygen -3.3 , nitrogen -3 , carbon -2 times). The hafnium samples refined by the zone recrystallization method were characterized by a purity of $99.85 \mathrm{wt}$. \%. The concentrations of both all metal impurities and interstitial impurities were significantly reduced (concentration in wt $\%$ oxygen was 0.011 , carbon -0.0018 , nitrogen $-5 \cdot 10^{-5}$ ). A study of gas evolution from samples of iodide hafnium and refined hafnium was carried out. It was found that the maximum gas release peak fell on the temperature range of $500 \ldots 550{ }^{\circ} \mathrm{C}$. The use of an integrated approach, including high-temperature heating, stages of zone melting at different rates, and thermal cycling in the range of the polymorphic transformation temperature, made it possible to obtain single-crystal hafnium samples. According to X-ray diffraction data, the parameters of the hafnium crystal lattice were determined: $a=\left(0.31950 \pm 5 \cdot 10^{-5}\right) \mathrm{nm}$ and $c=\left(0.50542 \pm 5 \cdot 10^{-5}\right) \mathrm{nm}$ (at $298 \mathrm{~K}$ ), which corresponds to the density $\rho=13.263 \mathrm{~g} / \mathrm{cm}^{3}$ and axial ratio $c / a=1.5819$.
\end{abstract}

KEYWORDS: zirconium, hafnium, zone recrystallization, electrotransport, thermal cycling, impurity composition, microhardness

In the next 30 years, the thermal neutron reactors will continue to occupy a dominant position among nuclear power units. The basic material for the active zones of such reactors are zirconium-based alloys, which have an optimal combination of nuclear, corrosion, mechanical, thermal and other physicochemical characteristics. An improvement of zirconium materials will increase the efficiency of existing power units, increase the depth of fuel burnup, extend the design life, ensure operational reliability and safety [1,2]. The industrial production of zirconium $(\mathrm{Zr})$ has led to an increase in the production of hafnium (Hf). A great deal of experience has been accumulated in the chemical separation of zirconium and hafnium, the technology of manufacturing materials with the required physical and mechanical characteristics has been improved, statistics have been accumulated on the duration of operation and the evolution of the properties of products operating in the cores of nuclear reactors.

Zirconium and hafnium belong to the elements of IVB group of Mendeleev's periodic table. The chemical properties of these metals are very similar, but the main applications in reactor construction are not the same due to the different neutron-physical characteristics. Hafnium is characterized by a high thermal neutron absorption cross section $(105 \pm 5 \mathrm{~b})$, which is three orders of magnitude higher than that of zirconium. Under radiation exposure, the hafnium absorption cross section decreases very slowly. This is due to the isotopic composition of hafnium and the peculiarities of isotope transmutation in the neutron flux. Therefore, it finds application in the manufacture of controls for control and protection systems of reactors. Hafnium has good mechanical and corrosive properties over a wide temperature range [3].

The interstitial and metallic impurities $(\mathrm{O}, \mathrm{C}, \mathrm{Si}, \mathrm{P}, \mathrm{Mg}, \mathrm{K}, \mathrm{Ca}, \mathrm{Cl}, \mathrm{F}, \mathrm{Ni}, \mathrm{H}$, etc.) have a negative effect on the structure and properties of zirconium and hafnium even in small amounts. This can lead to a change in mechanical and corrosion characteristics, as well as to changes in deformation and heat treatment modes. Therefore, experimenters are always interested in obtaining high-purity metal samples. The study of the characteristics of such samples makes it possible to more correctly assess the physical and mechanical properties associated with an own nature of metals.

The crystallization processes from melts are one of the main methods for refining metals and obtaining single crystals. They are used at the final stage of cleaning to remove small concentrations of impurities. Since zirconium and hafnium are characterized by high melting points and chemical activity, special physical purification methods are required. The conducting of zone melting in a vacuum allows cleaning both as a result of the zone separation of impurities and as a result of the evaporation process of impurities having a high saturated vapor pressure at the melting point of the base material.

The article discusses the possibilities of effective refining of zirconium and hafnium by the zone recrystallization method, including the use of electrotransport, the results of studies of the obtained samples are presented. 


\section{MATERIALS AND METHODS}

In the presented work, the process of refining zirconium and hafnium was carried out by the zone recrystallization method, including in an electric field, on a crucibleless electron-beam zone melting facility in a vacuum. A description of the process and experimental setup was presented in detail in an article [4].

The starting materials for the experiments were zirconium with a purity of $99.7 \mathrm{wt} . \%$ and hafnium with a purity of 99.58 wt. \%, obtained by the method of industrial iodide refining. The results of the content of impurities were obtained by laser mass spectrometry using an EMAL-2 analyzer. The limiting sensitivity of the analysis method for metal impurities was $\sim 10^{-5} \ldots 10^{-6}$ at. $\%$.

The use of the LECO TC-600 gas analyzer made it possible to determine the content of nitrogen and oxygen in the samples with an accuracy of $5 \cdot 10^{-8}$ at.\%. The device was calibrated with certified LECO samples.

The visual inspection of thin sections was carried out using an MMP-4 microscope. The microhardness was measured on a PMT-3 microhardness meter at loads of 0.05 and $0.1 \mathrm{kgf}$. The value of the microhardness numbers was recorded by ten measurements, the error did not exceed $5 \%$.

\section{ZONE RECRYSTALLIZATION METHOD}

The principle of zone refining is based on the practical use of the phenomenon of different solubility of impurities in the liquid and solid phases of the base material [5]. An important characteristic in the process description is the impurity distribution coefficient is $k$, which is the ratio of the impurity concentration in the solid phase $C_{S}$ to the concentration in the melt $C_{L}$ :

$$
k=C_{S} / C_{L} .
$$

It is distinguishing between the concepts of equilibrium distribution coefficient $k_{0}$ and effective distribution coefficient $k_{e}$. When solving most problems, the equilibrium coefficient $k_{0}$ is determined from the "base-impurity" state diagrams or by the ratio of the maximum solubility of an impurity to its concentration at the point of invariant transformation [6,7]. However, with such estimation methods, $k_{0}$ values can be calculated only in the case of a significant concentration of impurities in the base material.

When calculating the equilibrium distribution coefficient $k_{0}$ in the case of low impurity concentrations it is convenient to use the theoretical methods of calculations based on the thermodynamic constants of the equation of ideal solutions. According to this concept it be can use a special case of the Schroeder - Le Chatelier equation for refractory metals [8]:

$$
\begin{aligned}
\ln \frac{C_{L_{i}}}{C_{S_{i}}} & =-\frac{\Delta H_{i}}{R}\left(\frac{1}{T_{b}}-\frac{1}{T_{G_{i}}}\right)=\theta_{i} \\
\frac{C_{L_{i}}}{C_{S_{i}}} & =e^{\theta_{i}} \text { and } k_{0_{i}}=1 / e^{\theta_{i}}
\end{aligned}
$$

where $\Delta H_{i}$ is the molar heat of fusion of the $i$-th impurity $(\mathrm{J} / \mathrm{mol}), \mathrm{R}$ is the universal gas constant $(\mathrm{R}=8.314 \mathrm{~J} / \mathrm{mol} \cdot \mathrm{K})$, $T_{b}$ is the melting temperature of the basic substance $\left(T_{Z r}=2125 \mathrm{~K} ; T_{H f}=2500 \mathrm{~K}\right), T_{G i}$ is the estimated value of the melting temperature of the base-impurity alloy, which is selected from the state diagram "base metal - impurity".

For phase diagrams characterized by a continuous series of solid solutions, peritectic-type diagrams throughout the concentration range, as well as for impurities whose diagrams with the base metal are unknown, $T_{G i}$ is chosen equal to the melting temperature of the impurity element. In the case of phase diagrams with a number of eutectic and peritectic transformations value $T_{G i}$ is selected in order to meet the minimum transformation temperature of eutectic or peritectic type.

When conducting zone melting process, moving crystallization front pushes dissolved impurity faster than it can evenly distribute in the melt. Before crystallization front occurs, enriched impurity region called the diffusion layer. The diffusion layer thickness $\delta$ is dependent on the impurity diffusion capacity, the melt viscosity, the nature of the fluid motion, and the crystallization speed and it can be changed depending on the conditions of the melt mixing. The more intensive the stirring, the thinner the diffusion layer adjacent to the crystallized metal. The layer thickness $\delta$ can vary from $10^{-3} \mathrm{~cm}$ with vigorous stirring to $10^{-1} \mathrm{~cm}$ with weak stirring.

Therefore, the main characteristic of the zone separation is the effective distribution coefficient $k_{e}$, which for the $i$-th impurity can be calculated using the Barton-Prim-Slichter relation:

$$
k_{e_{i}}=\frac{1}{1+\left(\frac{1}{k_{0_{i}}}-1\right) \cdot e^{-\frac{v \delta}{d}}}
$$

where $v$ is the zone speed, $\delta$ is the diffusion layer thickness, and $d$ is the impurity diffusion coefficient in the melt [5]. 
The value of the impurity diffusion coefficient $d$ for most cases is in the range from $10^{-4}$ to $10^{-5} \mathrm{~cm}^{2} / \mathrm{s}$. The width of the diffusion layer $\delta$ in the case of moderate mixing of the melt in the liquid zone is assumed to be $0.01 \mathrm{~cm}$. Therefore, $\delta / d \approx 200 \mathrm{~s} / \mathrm{cm}$. The ratio $v \delta / d$ is called the reduced crystallization rate (it is a dimensionless quantity).

When zone melting of refractory metals is carrying out in vacuum, in addition to cleaning the material as a result of zone redistribution, refining also occurs due to the evaporation of impurities having a high saturated vapor pressure at the melting point of the base material. Thus, at the melting temperature of zirconium $\left(T_{Z r}=2125 \mathrm{~K}\right)$ or hafnium $\left(T_{H f}=2500 \mathrm{~K}\right)$, one should expect a decrease in the concentration of a number of metallic impurities ( $\mathrm{Al}, \mathrm{Ca}, \mathrm{Cu}, \mathrm{Fe}$, $\mathrm{Mn}, \mathrm{Ni}, \mathrm{Si}$, Ti, etc.). The reduced evaporation coefficient $g_{i}$ for the $i$-th impurity (it is a dimensionless quantity) can be expressed by the formula:

$$
g_{i}=\frac{2 \alpha_{i} \gamma_{i} p_{i}^{o} V l}{17.16 \cdot v r \sqrt{\frac{A_{i} T_{b}}{\eta_{i}}}},
$$

where $\alpha_{i}$ is the Langmuir coefficient; $p_{i}^{0}$ is the saturated vapor pressure at a melting temperature, torr; $\gamma_{\mathrm{i}}$ is the activity coefficient; $A_{i}$ is the atomic weight in the condensed phase; $\eta_{i}$ is the number of atoms in a vapor molecule; $V=A_{b} / \rho_{b}$ atomic (molar) volume of the main component; $r$ is the radius of the molten zone, $l$ is the length of the zone, and $v$ is the velocity of the zone [9].

After several passes of zone melting with a low speed of zone movement $(1 \mathrm{or} 2 \mathrm{~mm} / \mathrm{min})$, in the middle part of the refined sample a region of quasi-stationary concentration is established. The concentration of the $i$-th impurity after the $n$-th number of passes $C_{n i}$ in the quasi-stationary region is related to the initial concentration of $C_{o i}$ by the ratio, which is valid only when considering the case of low concentrations of impurities:

$$
\tilde{N}_{n_{i}} / C_{o_{i}}=\left(\frac{k_{e_{i}}}{k_{e_{i}}+g_{i}}\right)^{n} .
$$

The passing of a direct electric current through the metal sample leads to the displacement of both matrix ions and impurity ions to the anode or cathode. The current passing through the phase boundary changes the value of the effective distribution coefficient ke due to the addition of the electric transport component to the diffusion flux. In the case of zone melting in an electric field equation (3) for the effective impurity distribution coefficient $k_{e i}{ }^{\prime}$ takes the form:

$$
k_{e_{i}}^{\prime}=\frac{1+\frac{\nu^{\prime}}{v}}{1+\left[\frac{1}{k_{0_{i}}}\left(1+\frac{\nu^{\prime}}{v}\right)-1\right] \cdot e^{-\frac{v \delta}{D_{i}}\left(1+\frac{v^{\prime}}{v}\right)},}
$$

where $D_{i}$ is the diffusion coefficient of the impurity ion; $v^{\prime}$ is the speed of movement of the impurity ion.

\section{RESULTS AND DISCUSSION}

To obtain high-purity samples of zirconium or hafnium the method of vertical crucibleless zone melting (ZM) of round rods in a vacuum of $1 \cdot 10^{-4} \mathrm{~Pa}$ with electron-beam heating was chosen. The advantages of this technique include: the ability to grow single crystals of refractory metals and alloys with a melting point above $2000 \mathrm{~K}$, no crucible, creation of a narrow heating area by focusing the electron beam, high specific power concentration [10].

The process of cleaning of metals was carried out in several stages. After the initial billet was heated (for the purpose of degassing) and carrying out the ZM at different speeds (from 16 to $1 \mathrm{~mm} / \mathrm{min}$ ), the samples were obtained in the form of cylindrical rods with a length of 100 to $300 \mathrm{~mm}$ and a diameter of up to $10 \mathrm{~mm}$ (Fig. 1).

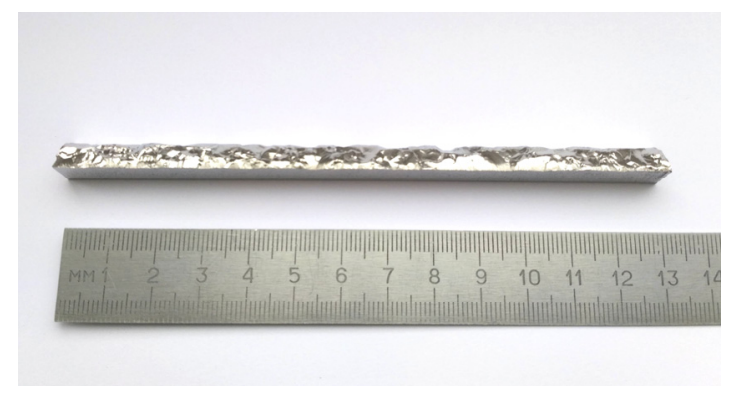

a

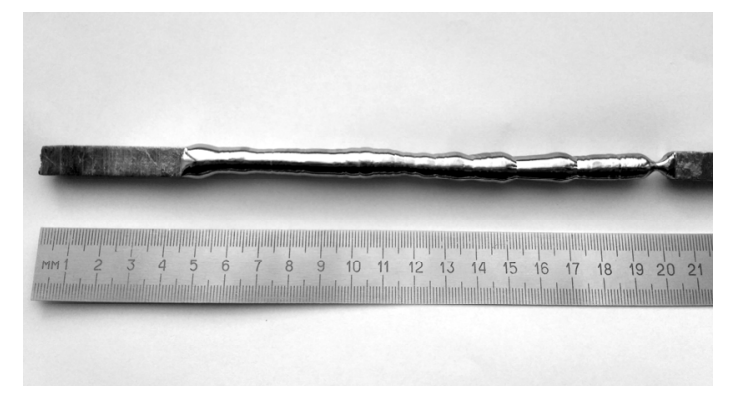

b

Figure 1. The samples of zirconium before (a) and after (b) zone recrystallization

Calculations of the equilibrium coefficient $k_{0 i}$ and effective distribution coefficient $k_{e i}$ allowed us to conclude that when carrying out the zone melting, due to the different solubility of impurities in the liquid and solid phases of zirconium, it is possible to carry out refining from the majority of metallic impurities ( $\mathrm{Al}, \mathrm{Be}, \mathrm{Fe}, \mathrm{Ca}, \mathrm{Si}, \mathrm{Mn}, \mathrm{Cu}$, etc.). 
Small amounts of these impurities lower the melting point of zirconium, and for them $k_{0 i}<1$ [11]. For effective refining of zirconium from metal impurities with $k_{e i}<1$, two or three passes of the zone melting with a low speed $v=2 \mathrm{~mm} / \mathrm{min}$ are sufficient (Table 1).

The estimates of the values of the reduced evaporation coefficient $g_{i}$ and the assumed concentration of impurities $C_{n i}$ in the quasi-stationary region were carried out for the stages of zone melting at different rates according to formulas (5) and (6). The performed calculation of $C_{n i}$ for a speed of $2 \mathrm{~mm} / \mathrm{min}$ showed that those impurities for which $g_{i}>1.2$ will be effectively removed during the evaporation process ( $\mathrm{Al}, \mathrm{Be}, \mathrm{Ca}, \mathrm{Si}, \mathrm{Cu}, \mathrm{Mn}, \mathrm{Pb}, \mathrm{Cr}$ ).

Also Table 1 shows the calculations of the equilibrium distribution coefficient $k_{0, l i m}$, taken from the article [12].

Table 1. The calculated values of equilibrium coefficient $k_{0 i}$ and effective distribution coefficient $k_{e i}$, reduced evaporation coefficient $g_{i}$, assumed concentration $C_{n i}$ for the $i$-th impurity in $\mathrm{Zr}$, and results of chemical analysis of zirconium samples after zone melting

\begin{tabular}{|c|c|c|c|c|c|c|c|}
\hline Element & $\begin{array}{c}C_{0 i} \\
\text { wt. \% }\end{array}$ & $k_{0 i}$ & $k_{0, \text { lim }}[12]$ & $k_{e i}$ & $\begin{array}{c}g_{i} \\
\text { at } v=2 \mathrm{~mm} / \mathrm{min}\end{array}$ & $\begin{array}{c}C_{n i} \text { after two } \\
\text { passes with } \\
v=2 \mathrm{~mm} / \mathrm{min}\end{array}$ & $\begin{array}{c}\text { Chemical } \\
\text { analysis after } \\
\text { ZM }\end{array}$ \\
\hline $\mathrm{Zr}$ & 99.7 & 1 & 1 & 1 & $2.2 \cdot 10^{-6}$ & - & 99.87 \\
\hline $\mathrm{Al}$ & $2.2 \cdot 10^{-4}$ & 0.46 & $<0.42$ & 0.62 & 7.21 & $1.4 \cdot 10^{-6}$ & $7 \cdot 10^{-6}$ \\
\hline $\mathrm{Be}$ & $<1 \cdot 10^{-5}$ & 0.60 & $<1$ & 0.74 & 5.35 & $1.5 \cdot 10^{-7}$ & $<1 \cdot 10^{-5}$ \\
\hline $\mathrm{Hf}$ & 0.075 & 1.23 & $>1$ & 1.1 & $8 \cdot 10^{-8}$ & 0.075 & $0 / 052$ \\
\hline $\mathrm{Fe}$ & $8.5 \cdot 10^{-3}$ & 0.54 & 0.27 & 0.70 & 0.21 & 0.005 & $7,5 \cdot 10^{-4}$ \\
\hline $\mathrm{Ca}$ & $2 \cdot 10^{-5}$ & 0.62 & - & 0.76 & 118.4 & $8 \cdot 10^{-10}$ & $1,3 \cdot 10^{-5}$ \\
\hline $\mathrm{Si}$ & $2.3 \cdot 10^{-4}$ & 0.43 & $<1$ & 0.59 & 7.07 & $1.4 \cdot 10^{-6}$ & $7 \cdot 10^{-5}$ \\
\hline $\mathrm{Mn}$ & $4.5 \cdot 10^{-5}$ & 0.68 & $<1$ & 0.80 & 144.4 & $1.4 \cdot 10^{-9}$ & $<5 \cdot 10^{-6}$ \\
\hline $\mathrm{Cu}$ & $9.5 \cdot 10^{-4}$ & 0.54 & 0.101 & 0.70 & 1.34 & $1 \cdot 10^{-4}$ & $<1 \cdot 10^{-5}$ \\
\hline $\mathrm{Mo}$ & $<6 \cdot 10^{-5}$ & 0.77 & 0.392 & 0.87 & $8.7 \cdot 10^{-8}$ & $6 \cdot 10^{-5}$ & $<6 \cdot 10^{-5}$ \\
\hline $\mathrm{Ni}$ & $4 \cdot 10^{-3}$ & 0.49 & $<1$ & 0.65 & 11.46 & $1.1 \cdot 10^{-5}$ & $2 \cdot 10^{-3}$ \\
\hline $\mathrm{Nb}$ & $<5 \cdot 10^{-5}$ & 0.92 & 0.634 & 0.95 & $5.5 \cdot 10^{-9}$ & $5 \cdot 10^{-5}$ & $<5 \cdot 10^{-5}$ \\
\hline $\mathrm{Pb}$ & $<1 \cdot 10^{-4}$ & 0.50 & $<1$ & 0.66 & 74.37 & $7.7 \cdot 10^{-9}$ & $<1 \cdot 10^{-4}$ \\
\hline $\mathrm{Ti}$ & $5 \cdot 10^{-4}$ & 0.83 & $<1$ & 0.90 & 0.001 & $5 \cdot 10^{-4}$ & $5 \cdot 10^{-4}$ \\
\hline $\mathrm{Cr}$ & $3.5 \cdot 10^{-3}$ & 0.68 & $<1$ & 0.80 & 5 & $6.5 \cdot 10^{-5}$ & $5 \cdot 10^{-6}$ \\
\hline
\end{tabular}

In order to obtain large metal grains, the experiments were carried out using slow heating and cooling of the ingot (stage of thermal cycling) in the range of polymorphic transformation temperature, which for zirconium is $1138 \mathrm{~K}$. Thermal cycling was carried out for $4 . . .6$ hours. Metallographic studies showed the presence of large metal grains with sizes from 5 to $10 \mathrm{~mm}$. The use of a complex purification procedure, including preliminary heating, stages of vacuum zone melting and thermal cycling, made it possible to obtain samples of zirconium with a purity of $99.87 \mathrm{wt}$. \%.

The concentration of impurities was significantly reduced (for example, the concentration of Hf decreased by 1.5 , $\mathrm{O}$ - by $2.7, \mathrm{C}$ - by 1.6 times, metal impurities - by $1.5 \ldots 700$ times) (Table 1 ).

The study of the possibility of zirconium refining by the method of vacuum electron-beam melting was also carried out in an electric field (ZMEF method), included both in the direction of the zone melting and against the course of the zone. The process of directional bias of interstitial impurities during electrotransport takes place actively both in the $\beta$-phase and in the molten metal zone. When the field was connected against the course of the melting, the ions of interstitial impurities, characterized by a negative value of effective charge of the impurity ion $Z^{*}$, were displaced to the positive pole (anode) (according to the results of work [13]). Moreover, in this case, the movement of ions coincided with the direction of movement of the liquid zone. This significantly increased the efficiency of refining by the ZMEF method. In work [14], the parameters of the ZMEF process were calculated for interstitial impurities: the values of the impurity ion mobility $U$, the diffusion coefficient $D$, the movement velocity of the impurity ion $v^{\prime}$, the effective impurity distribution coefficient $k_{e}{ }^{\prime}$. In carrying out the calculations, the values of the melting parameters were used: the electric field strength $E=0.013 \mathrm{~V} / \mathrm{cm}$, the melting speed $v=0.066 \mathrm{~cm} / \mathrm{s}$ (Table 2).

Table 2. The results of calculating the parameters of the ZMEF process for interstitial impurities in zirconium

\begin{tabular}{|c|c|c|c|c|c|c|c|}
\hline \multirow{2}{*}{ Impurity } & \multirow{2}{*}{$Z^{*}[13]$} & \multirow{2}{*}{$\begin{array}{c}U, 10^{-5} \\
\mathrm{~cm}^{2} /(\mathrm{V} \cdot \mathrm{s})\end{array}$} & \multirow{2}{*}{$\begin{array}{l}D, 10^{-6}, \\
\mathrm{~cm}^{2} / \mathrm{s}\end{array}$} & \multirow{2}{*}{$\begin{array}{c}\left|v^{\prime}\right|, 10^{-7} \\
\mathrm{~cm} / \mathrm{s}\end{array}$} & \multirow{2}{*}{$\begin{array}{c}k_{e} \\
\text { at ZM }\end{array}$} & $k_{e}^{\prime}$ & $k_{e}^{\prime}$ \\
\hline & & & & & & $\vec{E} \uparrow \uparrow \vec{v}$ & $\vec{E} \nmid \downarrow \vec{v}$ \\
\hline $\mathrm{O}$ & -1 & 1.8 & 3.3 & 2.34 & 1.15 & 1.01 & 0.99 \\
\hline $\mathrm{C}$ & -0.2 & 0.9 & 8.25 & 1.17 & 0.95 & 0.96 & 0.95 \\
\hline $\mathrm{N}$ & -0.7 & 1.2 & 3.14 & 1.56 & 1.03 & 1.01 & 0.99 \\
\hline
\end{tabular}


The refining of zirconium from gas-forming impurities took place at various stages of the experiments. Thus, hydrogen was evaporated in the form of gaseous molecules $\left(\mathrm{H}_{2}, \mathrm{H}_{2} \mathrm{O}\right)$ during preliminary heating and melting at a high speed. The carbon was volatilized as $\mathrm{CO}$ and $\mathrm{CO}_{2}$ molecules. The refining process also took place due to the displacement of metal carbides into the end of the ingot. Nitrogen was evaporated in the form of $\mathrm{N}_{2}$ gas molecules during high-temperature heating and zone melting. A decrease in the oxygen content occurred at the stages of heating and $\mathrm{ZM}$ as a result of the formation of gaseous molecules $\left(\mathrm{CO}, \mathrm{CO}_{2}, \mathrm{H}_{2} \mathrm{O}\right)$. Oxygen removal could also occur due to the displacement of refractory oxides (for example, $\mathrm{ZrO}_{2}, \mathrm{HfO}_{2}$ ) during recrystallization to the end of the sample. In the purest samples of zirconium, the concentration of oxygen was reduced by 3.3 , nitrogen -3 , carbon -2 times. The results of the analysis of the elemental composition showed an insignificant content of a number of metallic impurities in the refined ingots, which were removed during the simultaneous passage of the processes of evaporation, zone recrystallization and melting with electric transfport. Thus, the concentration of aluminum was reduced by 5 , iron -11 , nickel -2 , copper -45 , chromium -75 , silicon -10 , titanium -2.5 times. There was a slight decrease in the concentration of hafnium (from 0.075 to $0.05 \mathrm{wt} \%$ ). The content of molybdenum and niobium after heats did not change and remained at the level of $2 \cdot 10^{-4}$ and $1 \cdot 10^{-4} \mathrm{wt} . \%$ respectively. The purity of the refined samples was characterized by a value of $99.89 \mathrm{wt}$ \% by zirconium content.

When carrying out a cycle of works on zone recrystallization of hafnium, the coefficients $k_{0 i}, k_{e i}, g_{i}, C_{n i}, k_{e}{ }^{\prime}$ were calculated using formulas (2-5) (Table 3). A detailed description of the calculations was given in the articles [15, 16]. Also Table 3 shows the calculations of the equilibrium distribution coefficient $k_{0, \text { lim }}$, taken from the the article [12].

Table 3. The calculated values of equilibrium coefficient $k_{0 i}$ and effective distribution coefficient $k_{e i}$, reduced evaporation coefficient $g_{i}$, assumed concentration $C_{n i}$ for the $i$-th impurity in Hf, and results of chemical analysis of hafnium samples after zone melting

\begin{tabular}{|c|c|c|c|c|c|c|c|}
\hline Element & $\begin{array}{c}C_{0 i,} \\
\text { wt. \% }\end{array}$ & $k_{0 i}$ & $k_{0, \text { lim }}[12]$ & $k_{e i}$ & $\begin{array}{c}g_{i} \\
\text { at } v=2 \\
\mathrm{~mm} / \mathrm{min}\end{array}$ & $\begin{array}{c}C_{n i} \text { after two } \\
\text { passes with } \\
v=2 \mathrm{~mm} / \mathrm{min}\end{array}$ & $\begin{array}{c}\text { Chemical } \\
\text { analysis after } \\
\text { ZM }\end{array}$ \\
\hline $\mathrm{Hf}$ & 99.58 & 1 & 1 & 1 & 0.001 & - & $99.75 \ldots 99.8$ \\
\hline $\mathrm{Zr}$ & 0.23 & 0.85 & 0.73 & 0.91 & 0.0099 & 0.225 & 0.21 \\
\hline $\mathrm{Al}$ & 0.003 & 0.42 & 0.71 & 0.58 & 402.8 & $6.3 \cdot 10^{-9}$ & $<1 \cdot 10^{-5}$ \\
\hline $\mathrm{W}$ & 0.0002 & 0.81 & 0.49 & 0.89 & $2.8 \cdot 10^{-5}$ & 0.0002 & 0.00013 \\
\hline $\mathrm{Fe}$ & 0.007 & 0.68 & 0.12 & 0.80 & 11.45 & $3 \cdot 10^{-5}$ & $4 \cdot 10^{-4}$ \\
\hline $\mathrm{Ca}$ & 0.01 & 0.58 & - & 0.72 & 1502 & $2.3 \cdot 10^{-9}$ & $<7 \cdot 10^{-6}$ \\
\hline $\mathrm{Si}$ & 0.004 & 0.26 & 0.42 & 0.40 & 89.72 & $7.9 \cdot 10^{-8}$ & $<4 \cdot 10^{-5}$ \\
\hline $\mathrm{Mg}$ & 0.003 & 0.47 & - & 0.63 & $3.85 \cdot 10^{4}$ & $8 \cdot 10^{-13}$ & $<5 \cdot 10^{-6}$ \\
\hline $\mathrm{Mn}$ & 0.0003 & 0.64 & 0.29 & 0.78 & $3.84 \cdot 10^{3}$ & $1.2 \cdot 10^{-11}$ & $<1 \cdot 10^{-5}$ \\
\hline $\mathrm{Cu}$ & 0.002 & 0.53 & - & 0.68 & 95.44 & $1 \cdot 10^{-7}$ & $1 \cdot 10^{-5}$ \\
\hline $\mathrm{Mo}$ & 0.07 & 0.80 & 0.71 & 0.88 & $7.7 \cdot 10^{-3}$ & 0.069 & 0.02 \\
\hline $\mathrm{Ni}$ & 0.01 & 0.53 & 0.05 & 0.68 & 11.17 & $3.3 \cdot 10^{-5}$ & $1 \cdot 10^{-4}$ \\
\hline $\mathrm{Nb}$ & 0.006 & 0.91 & 0.70 & 0.95 & $8.8 \cdot 10^{-4}$ & $6 \cdot 10^{-3}$ & 0.004 \\
\hline $\mathrm{Ti}$ & 0.003 & 0.76 & 0.66 & 0.86 & 1.37 & $4.4 \cdot 10^{-4}$ & $2 \cdot 10^{-4}$ \\
\hline $\mathrm{Cr}$ & 0.003 & 0.66 & 0.74 & 0.79 & 79.13 & $2.9 \cdot 10^{-7}$ & $<2 \cdot 10^{-5}$ \\
\hline
\end{tabular}

It was found that for the refining of hafnium, the zone melting method will be most efficiently applied when several stages of experiments are carried out sequentially, namely: 1) high-temperature heating, 2) zone melting at a big speed (16 or $8 \mathrm{~mm} / \mathrm{min}$ ) to remove highly volatile metallic impurities, 3) melting at a low speed (2 or $1 \mathrm{~mm} / \mathrm{min})$ for the display of the effect of impurity displacement of together with the movement of the liquid zone, 4) thermal cycling in the temperature range of polymorphic transformation. All operations must be carried out in a vacuum of at least $1 \cdot 10^{-4} \mathrm{~Pa}$.

Zone recrystallization made it possible to obtain hafnium samples with a purity of $99.88 \mathrm{wt}$. \%. The oxygen and carbon concentrations were lowered 1.5 times (from 0.03 to $0.02 \mathrm{wt}$. \% in oxygen, from 0.04 to 0.022 wt. \% in carbon), zirconium - from 0.23 to 0.065 wt. $\%$.

The use of the MX 7304A mass spectrometer made it possible to study the outgassing from hafnium iodide and refined hafnium samples (the weight of the samples was $0.93 \mathrm{~g}$ ). The experiments had shown that the maximum peak of gas release was in the temperature range of $500 \ldots 550{ }^{\circ} \mathrm{C}$. In this temperature range, the total gas pressure during heating of the refined sample was observed to be 10 times lower than during heat treatment of hafnium iodide (Fig. 2).

The change in the partial pressure of gases released from the hafnium iodide sample is shown in the diagram (Fig. 3, a). In the experiment, the amount of evolved gas in relation to the chamber volume was $0.0063 \%$. When the sample was heated to a temperature of $300{ }^{\circ} \mathrm{C}$, there was a slight increase in pressure, which is explained by the degassing of the original sample; gas evolution with a mass number of 18 (water vapor) prevailed. When heated from $300{ }^{\circ} \mathrm{C}$ to $550{ }^{\circ} \mathrm{C}$, the pressure increased due to the activation of the process of gas evolution with mass numbers 18 $\left(\mathrm{H}_{2} \mathrm{O}\right.$ ), 28 (carbon monoxide $\mathrm{CO}$ and nitrogen $\mathrm{N}_{2}$ ), 44 (carbon dioxide $\mathrm{CO}_{2}$ ). When heated above $700{ }^{\circ} \mathrm{C}$, the total gas pressure stabilized at the level of $1.2 \cdot 10^{-5} \mathrm{~mm} \mathrm{Hg}$. 


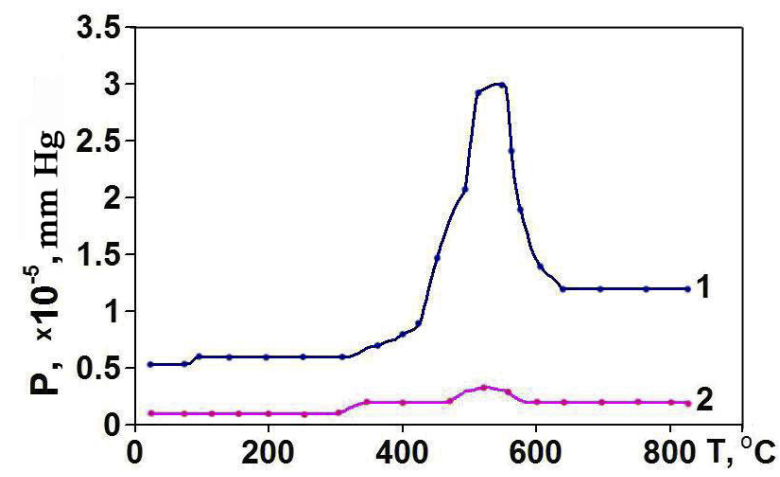

Figure 2. Gas evolution from samples of initial hafnium iodide (1) and refined hafnium (2)

The gas evolution from a sample of refined hafnium under heating is insignificant (total pressure $\mathrm{P} \approx 3 \cdot 10^{-6} \mathrm{~mm} \mathrm{Hg}$ ). The distribution of the partial pressure of gases is shown in Fig. 3, b. When heated to a temperature of $350{ }^{\circ} \mathrm{C} \ldots 400{ }^{\circ} \mathrm{C}$, some activation of the process of gas evolution with a mass number of $18\left(\mathrm{H}_{2} \mathrm{O}\right)$ was observed.

The study of gas evolution made it possible to optimize the temperature regime of the stage of preliminary heating of the hafnium sample. It is recommended to carry out heating in the range from $400{ }^{\circ} \mathrm{C}$ to $600{ }^{\circ} \mathrm{C}$.

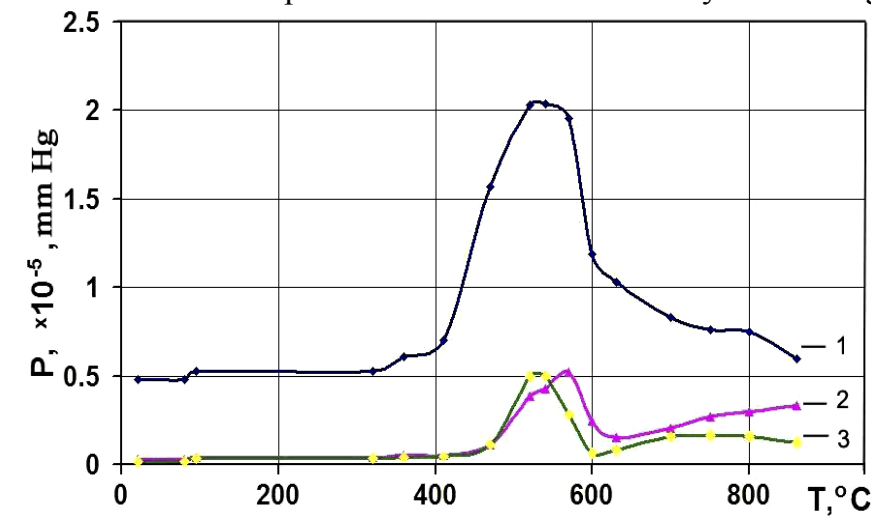

a

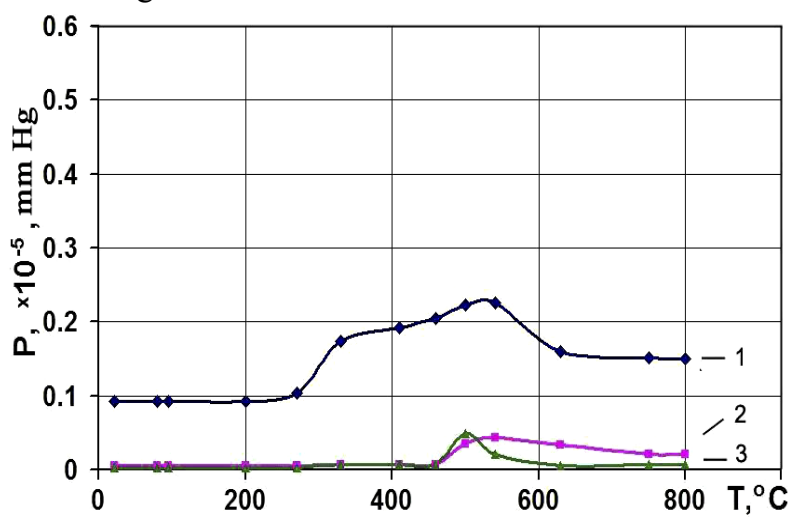

b

Figure 3. Partial pressure of gases released from samples of hafnium iodide (a) and refined hafnium (b), with mass numbers: 1) $\left.\left.18\left(\mathrm{H}_{2} \mathrm{O}\right), 2\right) 28\left(\mathrm{~N}_{2}, \mathrm{CO}\right), 3\right) 44\left(\mathrm{CO}_{2}\right)$

Vickers microhardness measurements of the samples showed that if for the initial hafnium iodide $\mathrm{H}_{\mu}=2700 \ldots 2850 \mathrm{MPa}$, then for the sample after zone melting with a high speed $\mathrm{H}_{\mu}=2050 \ldots 2200 \mathrm{MPa}$, for the sample after two passes at a speed of $2 \mathrm{~mm} / \mathrm{min}$ the value decreased to $\mathrm{H}_{\mu}=1200 \ldots 1400 \mathrm{MPa}$.

The refining of hafnium by the ZMEF method was carried out with a variability of connection (in the direction and against the movement of zone melting). Samples were cut from the purest part of the refined ingot $100 \mathrm{~mm}$ long for testing. The results of chemical analysis of refined hafnium samples indicate an insignificant content of $\mathrm{Al}, \mathrm{Ca}, \mathrm{Cu}, \mathrm{Si}$, $\mathrm{Ti}$, which were removed during the joint passage of the processes of zone recrystallization and evaporation. The concentration of iron was significantly reduced at the stages of zone melting (Table 4) [16].

Table 4. Results of chemical analysis of hafnium samples

\begin{tabular}{|c|c|c|c|c|c|c|c|c|c|c|c|c|}
\hline \multirow{2}{*}{ Materials } & \multicolumn{12}{|c|}{ Concentration of a chemical element, wt. $\%$} \\
\hline & Hf & $\mathrm{Zr}$ & $\mathrm{O}$ & $\mathrm{N}$ & $\mathrm{C}$ & $\mathrm{Al}$ & $\mathrm{Fe}$ & $\mathrm{Ca}$ & $\mathrm{Cu}$ & Mo & $\mathrm{Si}$ & $\mathrm{Ti}$ \\
\hline Hafnium iodide & 99.58 & 0.23 & 0.03 & 0.005 & & & 0.007 & 0.01 & 0.002 & 0.07 & 0.004 & 0.003 \\
\hline Hf after ZM & 99.75 & 0.21 & 0.02 & $4 \cdot 10^{-4}$ & 0.022 & $1 \cdot 10^{-5}$ & $4 \cdot 10^{-4}$ & $7 \cdot 10^{-6}$ & $1 \cdot 10^{-5}$ & 0.02 & $4 \cdot 10^{-5}$ & $2 \cdot 10^{-4}$ \\
\hline Hf ZMEF $\tilde{\mathrm{E}} \uparrow \uparrow \tilde{\mathrm{v}}$ & 99.81 & 0.17 & 0.013 & $8 \cdot 10^{-5}$ & 0.0021 & $<2 \cdot 10^{-6}$ & $5 \cdot 10^{-6}$ & $<3 \cdot 10^{-6}$ & $<3 \cdot 10^{-6}$ & 0.01 & $<1 \cdot 10^{-5}$ & $<5 \cdot 10^{-5}$ \\
\hline Hf ZMEF $\tilde{\mathrm{E}} \uparrow \downarrow \tilde{\mathrm{V}}$ & 99.85 & 0.12 & 0.011 & $5 \cdot 10^{-5}$ & 0.0018 & $<2 \cdot 10^{-6}$ & $2 \cdot 10^{-4}$ & $<3 \cdot 10^{-6}$ & $<3 \cdot 10^{-6}$ & 0.008 & $<1 \cdot 10^{-5}$ & $<5 \cdot 10^{-5}$ \\
\hline
\end{tabular}

In this work, the special attention was paid to the study of the distribution of interstitial impurities in hafnium after various stages of melting. Refining is especially effective when melting in an electric field coinciding with the direction of zone movement. The simultaneous passage of refining processes (evaporation of highly volatile impurities in vacuum, zone recrystallization, electrotransport) significantly increased the efficiency of hafnium purification from all types of impurities. High-purity hafnium samples with a low content of interstitial impurities were obtained. The oxygen concentration was 0.011 , carbon -0.0018 , nitrogen $-5 \cdot 10^{-5} \mathrm{wt} \%$. 
In Fig. $4(a, b)$ it is can see a zone with a low concentration of oxygen and carbon (within $20 \ldots 60 \mathrm{~mm}$ along the length of the ingot), closer to the end sections is slightly higher concentration. The redistribution of oxygen along the length of the ingot indicates the effect of an electrotransport. A significant decrease in the concentrations of carbon and nitrogen after ZMEF occurred as a result of evaporation and displacement during recrystallization (Table 4).

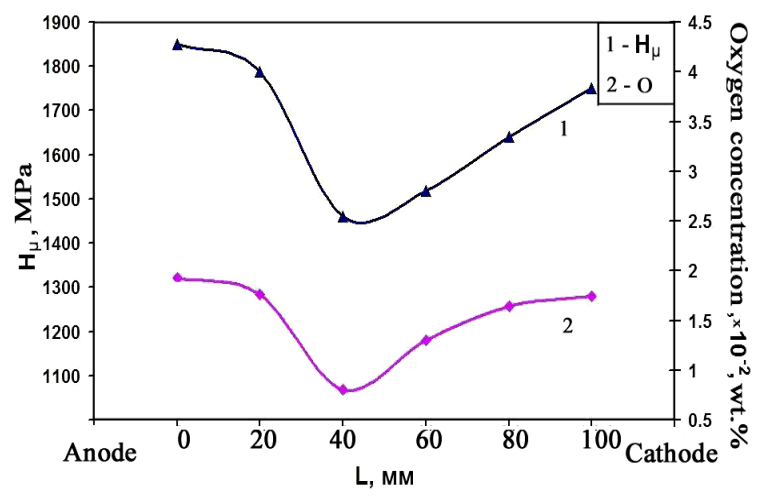

a

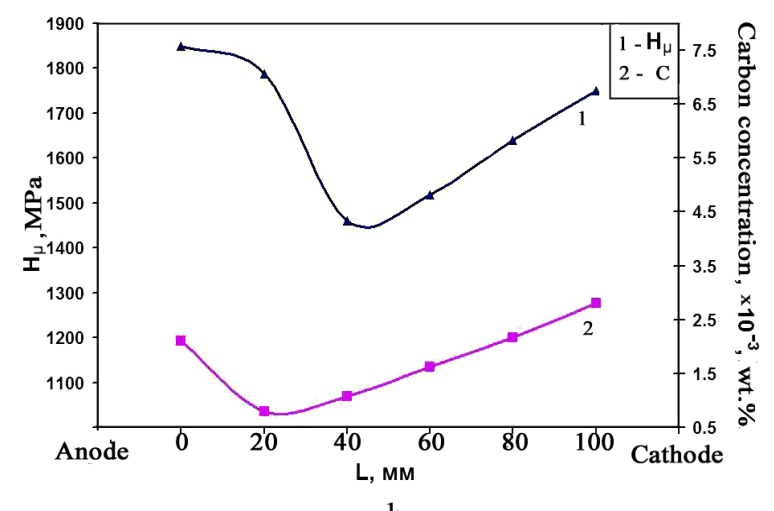

b

Figure 4. Dependence of the microhardness of hafnium on the impurity concentration after the ZMEF for: a) oxygen, b) carbon. The directions of the zone melting and the electric field coincided

The value of microhardness directly depends on the concentration of interstitial impurities (the minimum of microhardness falls on the minimum concentrations), and this dependence is most characteristic in relation to oxygen, the content of which is much higher than that of carbon and nitrogen. So, the minimum value of microhardness $\mathrm{H}_{\mu}=1460 \mathrm{MPa}$ was observed at an oxygen concentration of $0.008 \mathrm{wt} . \%$.

In order to obtain large grains of hafnium, experiments were carried out using slow heating and cooling of the ingot in the range of the polymorphic transformation temperature of $2033 \mathrm{~K}$ (thermal cycling stage). The experiment was carried out for $4 . . .6$ hours. Metallographic studies showed the presence of large grains up to $25 \mathrm{~mm}$ long, elongated along the ingot. By the method of electrical discharge cutting an ingot of hafnium was divided into cylindrical columns with a length of $10 \ldots 12 \mathrm{~mm}$ and a diameter of $8 \ldots 10 \mathrm{~mm}$. The ends of the samples were ground and etched to reveal the microstructure. The optical method using an MMP-4 microscope was used to visually study thin sections and photograph the grain structure.

The orientation of the single crystals with the separation of hep lattice directions [0001], [1010] was carried out on diffractometer DRON-1.0. The orientation accuracy was within \pm 1.5 , the crystal mosaic was $\pm 4^{\prime} \ldots 5^{\prime}$. Single-crystal samples had an arbitrary shape with a thickness of $\sim 3 \mathrm{~mm}$ along the selected crystallographic directions. The parameters of the crystal lattice of hafnium were determined from x-ray diffraction data: $a=\left(0.31950 \pm 5 \cdot 10^{-5}\right) \mathrm{nm}$ and $c=\left(0.50542 \pm 5 \cdot 10^{-5}\right) \mathrm{nm}$ (at $298 \mathrm{~K}$ ), which corresponds to a density $\rho=13.263 \mathrm{~g} / \mathrm{cm}^{3}$ and an axial ratio $c / a=1.5819$ [17].

\section{CONCLUSIONS}

The work investigates the possibilities of effective refining of zirconium and hafnium by the zone recrystallization method, including the experiments in an electric field. It is shown that zone melting with the variability of connecting the direction of the electric field makes it possible to obtain refined samples with a reduced content of metal and gasforming impurities. The best degree of purification was achieved when zone melting took place in an electric field directed opposite to the movement of the zone. As a result of the experiments, zirconium samples with a purity of 99.89 wt. \% and hafnium with a purity of 99.85 wt. \% were obtained. The use of an integrated approach to refining made it possible to obtain and study single-crystal samples of hafnium.

\section{ACKNOWLEDGMENTS}

The authors express their gratitude and deep appreciation to the junior researcher Yu.P. Bobrov for many years of cooperation, advice and valuable remarks when discussing the experimental results.

\section{ORCID IDs}

Oleh E. Kozhevnikov, https://orcid.org/0000-0002-9690-8931; Mykola M. Pylypenko https://orcid.org/0000-0001-8113-8578 (D) Maryna F. Kozhevnikova, https://orcid.org/0000-0003-2464-3847

\section{REFERENCES}

[1] D.L. Douglass. The Metallurgy of Zirconium, (Vienna: IAEA, 1971), pp. 466.

[2] A.S. Zaimovsky, E.V. Nikulina, N.G. Reshetnikov, Циркониевые сплавы в атомной энергетике [Zirconium Alloys in Atomic Energetics], (Energoatomizdat, Moscow, 1994), pp. 453. (in Russian)

[3] D.E. Thomas, and E.T. Hayes, Металлургия гафния [The Metallurgy of Hafnium], (Metallurgy, Moscow, 1967), pp. 310. (in Russian) 


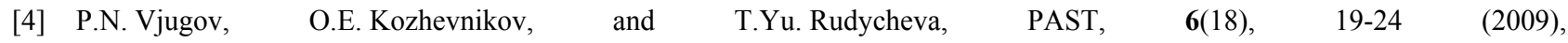
https://vant.kipt.kharkov.ua/ARTICLE/VANT_2009_6/article_2009_6_19.pdf. (in Russian)

[5] W.G. Pfann, Зонная плавка [Zone Melting], (Mir, Moscow, 1970), pp. 366. (in Russian)

[6] L.A. Niselson, and A.G. Yaroshevsky, Межфазовые коэффициенты распределения [Interphase distribution coefficients], (Nauka, Moscow, 1992), pp. 390. (in Russian)

[7] N.P. Lyakishev, Диаграммы состояния T.2 [State diagrams Vol.2], (Mashinostroyeniye, Moscow, 1997), pp. 1024. (in Russian)

[8] R.A. Laudise, and R.L. Parker, Рост монокристаллов [The Growth of Single Crystals], (Mir, Moscow, 1974), pp. 540. (in Russian)

[9] Sh.I. Peizulaev, Учет испарения примесей при зонной плавке [Taking into Account the Evaporation of Impurities in Zone Melting], Bulletin of the Academy of Sciences, Series "Inorganic Materials", 3(9), 1523-1532 (1967) (in Russian)

[10] G.F. Tikhinski, G.P. Kovtun, and V.M. Azhazha. Получение сверхчистых редких металлов [Obtaining of ultrapure rare metals], (Metallurgy, Moscow, 1986), pp. 160. (in Russian)

[11] O.E. Kozhevnikov, M.M. Pylypenko, Yu.S. Stadnik, V.D. Virich, M.F. Kozhevnikova, and I.G. Tantsyura, PAST, 5(117), 62-68 (2018), https://vant.kipt.kharkov.ua/ARTICLE/VANT_2018_5/article_2018_5_62r.pdf. (in Russian)

[12] L. Kuchar, B. Wozniakova and J. Dràpala. Segregation behavior during the zone melting of refractory metals, Journal of Crystal Growth, 52, 359-366 (1981), https://doi.org/10.1016/0022-0248(81)90219-0.

[13] F.A. Schmidt, O.N. Carlson, and C.E. Swanson, Metallurgical Transactions, 1, 1371-1374 (1970), https://doi.org/10.1007/BF02900257.

[14] O.E. Kozhevnikov, M.M. Pylypenko, Yu.S. Stadnik, and R.V. Azhazha, PAST, 1(125), 27-34 (2020), https://vant.kipt.kharkov.ua/ARTICLE/VANT_2020_1/article_2020_1_27.pdf. (in Russian)

[15] O.E. Kozhevnikov, P.N. Vjugov, M.M. Pylypenko, and V.D. Virich, The Journal of Kharkiv National University, Series "Nuclei, Particles, Fields", 4(60), 81-86 (2013), https://periodicals.karazin.ua/eejp/article/view/12908/12230. (in Russian)

[16] O.E. Kozhevnikov, P.N. Vjugov, and M.M. Pylypenko, PAST, 2015), https://vant.kipt.kharkov.ua/ARTICLE/VANT_2015_2/article_2015_2_89r.pdf. (in Russian)

[17] O.E. Kozhevnikov, M.M. Pylypenko, A.S. Bulatov, P.N. Vjugov, V.S. Klochko, and A.V. Korniets. PAST, 1(113), 54-61 (2018), https://vant.kipt.kharkov.ua/ARTICLE/VANT_2018_1/article_2018_1_54r.pdf. (in Russian)

\section{ЗОННА ПЕРЕКРИСТАЛІЗАЦІЯ ЦИРКОНІЮ ТА ГАФНІЮ}

О.С. Кожевніков, М.М. Пилипенко, М.Ф. Кожевнікова

Національний науковий центр «Харківський фізико-технічний інститут», НАНУ вул. Академічна, 1, 61108, Харків, Украӥна

В роботі вивчено можливості отримання високочистих зразків цирконію та гафнію методом зонної перекристалізації круглих стрижнів 3 електронно-променевим нагрівом у вакуумі $1 \cdot 10^{-4}$ Па. Частина плавок було проведено в постійному електричному полі з варіативністю його підключення. Показано, що одночасне проходження декількох рафінуючих процесів (випаровування легковидаляємих металевих домішок, зонна перекристалізація зі спрямованим зміщенням домішок в кінцеву частину зразка, електроперенос) дозволили провести ефективне рафінування цирконію як від металевих домішок, так і від домішок впровадження. Найкращої ступені очищення було досягнуто при проведенні зонного плавлення в електричному полі, направленому протилежно руху зони. В цьому випадку зміщення іонів домішок впровадження збігалося 3 напрямком пересування рідкої зони. Було отримано зразки цирконію з чистотою 99,89 мас. \% (концентрація алюмінію було знижено в 5, заліза - 11 , міді - 45 , хрому - 75, кремнію - 10 , титану - 2,5, кисню - 3,3, азоту - 3 , вуглецю - 2 рази). Рафіновані методом зонної перекристалізації зразки гафнію характеризувалися чистотою 99,85 мас. \%. Було значно знижено концентрації як усіх металевих домішок, так і домішок впровадження (концентрація в мас.\% кисню склала 0,011 , вуглецю 0,0018 , азоту $-5 \cdot 10^{-5}$ ). Проведено дослідження газовиділення із зразків йодідного та рафінованого гафнію. 3'ясовано, що максимальний пік газовиділення припадав на температурний інтервал $500 \ldots 550{ }^{\circ} \mathrm{C}$. Застосування комплексного підходу, який включає високотемпературний прогрів, етапи зонного плавлення з різною швидкістю і термоциклювання в області температури поліморфного перетворення, дозволило отримати монокристалічні зразки гафнію. По результатам рентгеноструктурного аналізу було визначено параметри кристалічної решітки гафнію: $a=\left(0,31950 \pm 5 \cdot 10^{-5}\right)$ нм $\mathrm{i}$ $c=\left(0,50542 \pm 5 \cdot 10^{-5}\right)$ нм (при $\left.298 \mathrm{~K}\right)$, що відповідає щільності $\rho=13,263$ г $/ \mathrm{cm}^{3}$ та осьовому співвідношенню $c / a=1,5819$.

КЛЮЧОВІ СЛОВА: цирконій, гафній, зонна перекристалізація, електроперенос, термоциклювання, домішковий склад, мікротвердість. 